\title{
The Effect of Glucose and Tolbutamide on Immunoreactive Somatostatin Release from Perifused Pancreatic Islets of Normal and Streptozotocin Diabetic Rats
}

\author{
Tetsuro KOBAYASHI, Shinji SAWANO, Tokuji ITOH, \\ Shigemasa TAKEDA ${ }^{1}$ AND TOMOKUni KOKUBU ${ }^{2}$ \\ Department of Endocrinology and Metabolism, Toranomon Hospital, \\ Okinaka Memorial Institute for Medical Research and Asahi Life \\ Institute for Adult Diseases, Tokyo 107 ; First Department of \\ Medicine, Toho University School of Medicine 1 , Tokyo 143; \\ and Research Institute for Polymers and Textiles ${ }^{2}$, \\ Tsukuba, Ibaragi, 305, Japan
}

\begin{abstract}
The patterns of immunoreactive somatostatin (IRS) responses to glucose and tolbutamide were investigated in perifused pancreatic islets of both normal and diabetic rats.

The incubation chamber of the perifusion apparatus for the islets was devised with a $2.5 \mathrm{ml}$ disposable syringe. By the method of Lacy, the pancreatic islets were isolated from diabetic rats about 30 days after a single intravenous injection of streptozotocin (STZ, $60 \mathrm{mg} / \mathrm{kg}$ body weight) and from normal rats of comparable body weight. The fasting blood glucose was $437 \pm 3 \mathrm{mg} / 100 \mathrm{ml}$ in the diabetic rats and $120 \pm 5 \mathrm{mg} / 100 \mathrm{~m} l$ in normal ones. The concentration of IRS in each effluent was measured by the specific double antibody radioimmunoassay for somatostatin.

During the initial 20 min incubation period with the medium containing $2.8 \mathrm{~mm}$ glucose, the levels of IRS were $11.3 \pm 1.0 \mathrm{pg} / 100$ islets $/ 2 \mathrm{~min}$ in normal islets and $32.0 \pm$ $3.4 \mathrm{pg} / 100$ islets $/ 2 \mathrm{~min}$ in diabetic islets. The latter value was significantly higher than the former $(\mathrm{p}<0.001)$. IRS levels gradually rose following $16.7 \mathrm{~mm}$ glucose and reached the maximal values with $30.2 \pm 5.7 \mathrm{pg} / 100$ islets $/ 2 \mathrm{~min}$ at $66 \mathrm{~min}$ in normal islets and with $56.8 \pm 13.3 \mathrm{pg} / 100$ islets $/ 2 \mathrm{~min}$ at $88 \mathrm{~min}$ in diabetic islets. The levels of IRS in diabetic islets were significantly higher than those of normal islets $(p<0.001)$ throughout the experimental period. In the case of tolbutamide the IRS levels increased promptly to $51.9 \pm 6.6 \mathrm{pg} / 100$ islets $/ 2 \mathrm{~min}$ in diabetic islets and to $23.7 \pm 4.6 \mathrm{pg} /$ 100 islets $/ 2 \mathrm{~min}$ in normal islets $2 \mathrm{~min}$ after initiation of the infusion. The former value was significantly higher than the latter $(\mathrm{p}<0.001)$. The levels of immunoreactive glucagon (IRG) in response to tolbutamide were significantly higher in the diabetic islets than in normal islets $(\mathrm{p}<0.001)$. These results indicate that there exists a hypersecrecretion of IRS from STZ-induced diabetic rats during the infusion with glucose and tolbutamide.
\end{abstract}

It is well established that immunoreactive somatostatin (IRS) is distributed widely in the extrahypothalamic tissues and organs including the pancreas and gastrointestinal tracts (Arimura et al., 1975; Hök-

\footnotetext{
Received December 1, 1979.

This work was supported in part by the grant from the Ministry of Education, Japan.
}

felt et al., 1975). Immunohistochemical studies clearly demonstrated that IRS existed in D-cells of the islets of Langerhans (Dubois, 1975). Exogenously administered somatostatin inhibits the release of insulin (IRI) (Alberti et al., 1973) and glucagon (IRG) (Koerker et al., 1974). On the other hand, glucose (Schauder et al., 1976, 1977; Ipp et al., 1977a) amino acids (Ipp et al., 


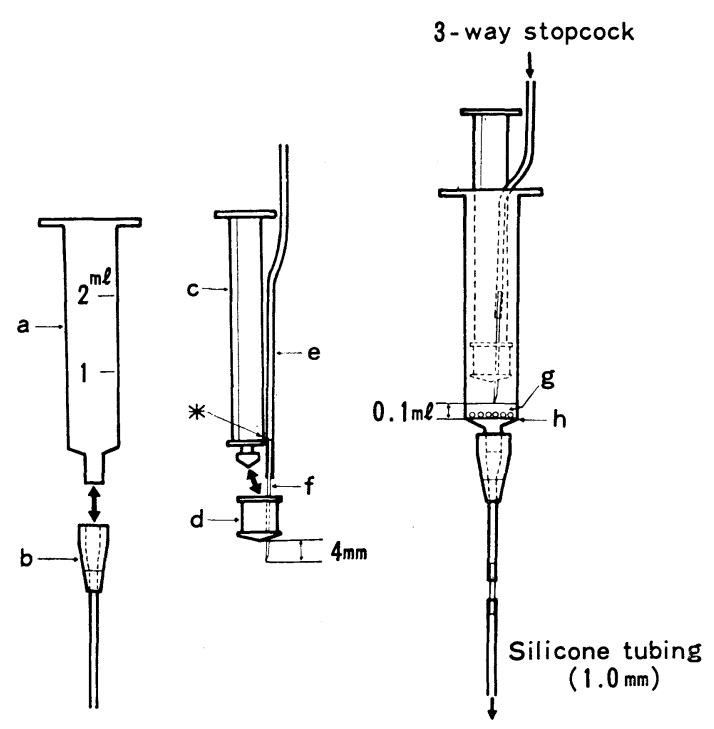

Fig. 1-(A). Incubation chamber. The components of units are designated as follows: (a) barrel of $2.5-\mathrm{m} l$ disposable syringe; (b) connector of 18gauge scalp vein set; (c) plunger of $2.5-\mathrm{m} l$ disposable syringe; (d) rubber gasket; (e) Tygon tubing (i.d. 0.025 in.); (f) 18-gauge steel needle; (g) islets; (h) glass filter paper (Whatman GF/A); $\left(^{*}\right)$ It was necessary to cut away part of the plunger base to allow insertion of the needle with the attached tubing.

1977a), tolbutamide (Ipp et al., 1977a) and gastrointestinal hormones (Ipp et al., 1977a, b) have been reported to stimulate the release of endogenous IRS from isolated perfused pancreas, or from isolated perifused pancreatic islets. These observations led to a postulation that IRS in D-cells of the islets may play a physiological role on the regulation of pancreatic endocrine functions (Unger, 1977).

In the islets of diabetic rats and humans, the hypertrophy and hyperplasia of D-cells are observed (Orci et al., 1976). These morphological changes are associated with an increase in somatostatin content in the D-cells (Patel and Weir, 1976). The secretory dynamics of somatostatin from the Dcells of diabetic islets are not fully understood. In the present study, we investigated the responses of IRS as well as IRI and IRG in the islets of diabetic rats to glucose and tolbutamide using the in vitro perifusion apparatus for the pancreatic islets which had been developed in our laboratory.

\section{Materials and Methods}

Male Wistar rats weighing $250-300 \mathrm{~g}$ were used in this study. Rats with diabetes induced by a single intravenous injection of STZ $(60 \mathrm{mg} / \mathrm{kg}$ body weight) were kept on a normal diet and water ad lib. for 30-40 days. The rats were anesthetized by Nembutal $(50 \mathrm{mg} / \mathrm{kg})$ and their peripheral blood was drawn from the jugular vein. Blood glucose level was determined by the glucose oxidase method using the Blood SugarGOD-Perid-Test (Boehringer-Mannheim Co. Ltd.). Pancreatic islets were isolated by the method of Lacy et al. $(1967,1972)$ using collagenase (Type IV, Worthington Biochemical Co., Freehole, New Jersey) at a dose of $25 \mathrm{mg}$ per pancreas.

The perifusion apparatus for rat adenohypophysis (Sawano et al., 1977) was modified as illustrated in Fig. 1-(A). Two chambers, one for normal islets (control group) and the other for diabetic islets (diabetic group), were composed of $2.5 \mathrm{~m} l$ disposable syringes (Termo). This system was devised for comparing simultaneously the dynamics of IRS release from diabetic islets and from normal islets. One hundred and fifty to two hundred islets from normal and STZ diabetic rats were placed in each incubation chamber of which the volume was adjusted to $0.1 \mathrm{~m} l$. The medium used was Krebs-Ringer-bicarbonate buffer containing $0.1 \%$ human serum albumin (Worthington Biochemical Co., Freehole, New Jersey) and $2.8 \mathrm{~mm}$ glucose at $\mathrm{pH} 7.4$ and was equilibrated with $95 \% \quad \mathrm{O}_{2}-5 \% \mathrm{CO}_{2}$ mixture before use. As illustrated in Fig. 1-(B), two incubation chambers, one medium reservoir and one sample chamber were all immersed in a water bath at $37^{\circ} \mathrm{C}$. The medium was pumped from the reservoir through the incubation chamber by a two-channel peristaltic pump. Preincubation was carried out at a rate of $0.5 \mathrm{~m} / / \mathrm{min}$ for $90 \mathrm{~min}$, and then the effluent from each incubation chamber was collected every two $\min (1.0 \mathrm{~m} l$ per fraction) in glass test tubes immersed in ice-cold water on the fraction collectors. The following materials were dissolved in the medium saturated with $95 \% \mathrm{O}_{2}-5 \%$ $\mathrm{CO}_{2}$ immediately before use, and infused into the system by means of the three-way stopcocks: the final concentrations of glucose and tolbutamide (Hoechst Japan, Ltd.) were adjusted to $16.7 \mathrm{~mm}$ and $400 \mu \mathrm{g} / \mathrm{m} l$, respectively.

Assay of IRS in the effluent was performed by radioimmunoassay (RIA) for somatostatin using antisomatostatin serum (R501, Sawano et al., 1978; Ku- 


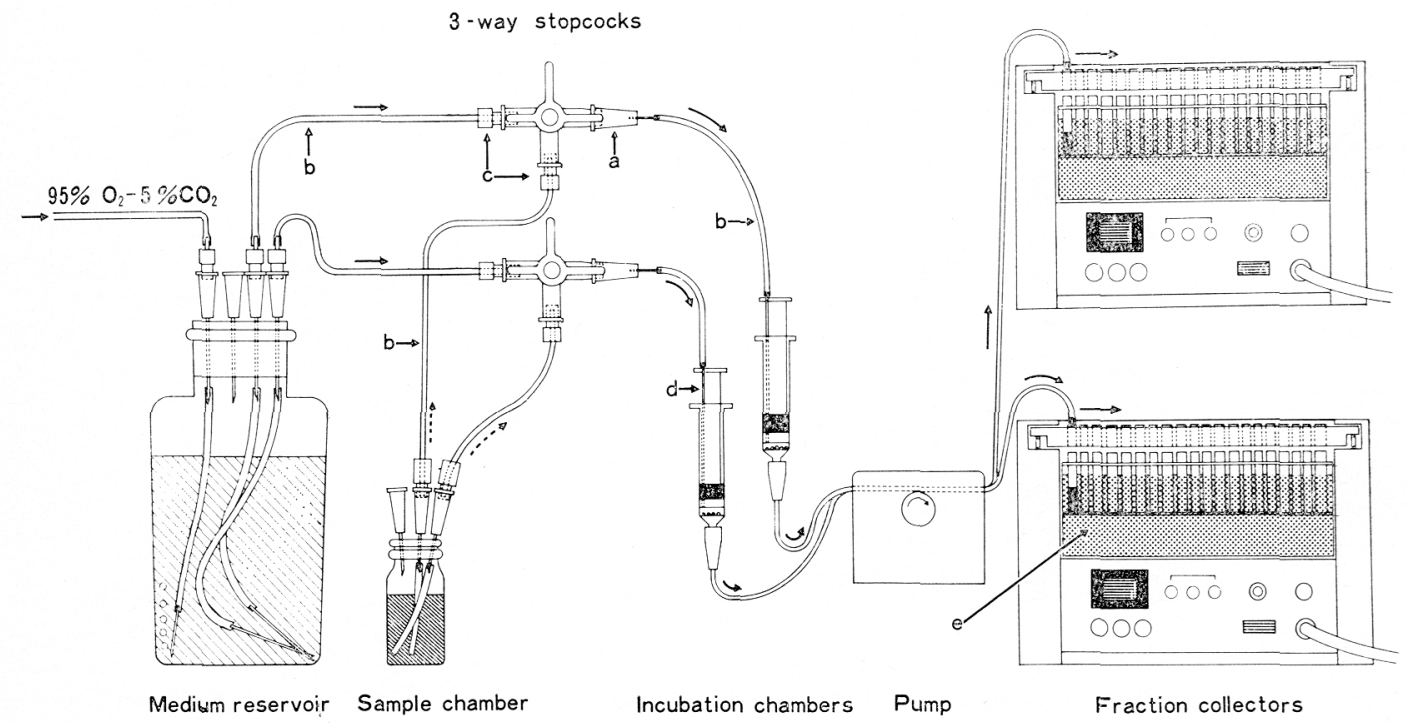

Fig. 1-(E). Diagram of the perifusion apparatus. (a) 18-gauge steel needle; (b) Tygon tubing (i.d. 0.025 in.); (c) connector (the tip of $1-\mathrm{m} l$ disposable syringe barrel); (d) 18-gauge steel rced'e; (e) ice-cold water.

masaka et a1., 1979). IRI was measured by the double antibody method using Dinabot Kits (Dinabot Radioisotope Lab., Tokyo), and IRG by the dextran coated charcoal method using $30 \mathrm{~K}$ antiserum (Unger). The amount of hormone released was expressed as $\mathrm{pg} / 100$ islets $/ 2 \mathrm{~min}$ for IRS and IRG, and $\mu \mathrm{U} / 100$ islets/2 $\mathrm{min}$ for IRI. The results were statistically analyzed by Duncan's new multiple range test or Student's $t$-test.

\section{Results}

Blood giucose levels.

The blood glucose level in STZ-treated rats was $437 \pm 3 \mathrm{mg} / 100 \mathrm{ml}$ (Mean \pm S.E., N $=8$ ), which was significantly higher than that in control rats $(120 \pm 5 \mathrm{mg} / 100 \mathrm{ml}, \mathrm{N}$ $=8, \mathrm{p}<0.001)$.

\section{Displacement curve of effuent in somatos- tatin RIA.}

Fig. 2 shows the displacement curve of the effluent in the somatostatin RIA system. Serial dilutions of the effluent from the peri- fusion system were proportional and their dilution slopes paralleled those of synthetic somatostatin.

IRS, IRI and IRG released by glucose.

During the initial $20-\mathrm{min}$ incubation period with $2.8 \mathrm{~mm}$ glucose, the levels of IRS were $32.0 \pm 3.4 \mathrm{pg} / 100$ islets $/ 2 \mathrm{~min}$ in the diabetic group and $11.3 \pm 1.0 \mathrm{pg} / 100$ islets/2 $\mathrm{min}$ in the control group. The former value was significantly higher than the latter $(p<0.001)$. A significant elevation of IRS levels was observed $56 \mathrm{~min}$ after the initiation of the perifusion with $16.7 \mathrm{~mm}$ glucose in the diabetic group. Such a delayed response of IRS was also noticed in the control group. Then, the levels further rose and reached the maximal values with $56.8 \pm 13.3 \mathrm{pg} / 100$ islets $/ 2 \mathrm{~min}$ at $88 \mathrm{~min}$ in the diabetic group and with $30.2 \pm 5.7 \mathrm{pg} /$ 100 islets $/ 2 \mathrm{~min}$ at $66 \mathrm{~min}$ in the contro? group. Throughout the perifusion periods with $16.7 \mathrm{~mm}$ glucose, the levels of IRS in 


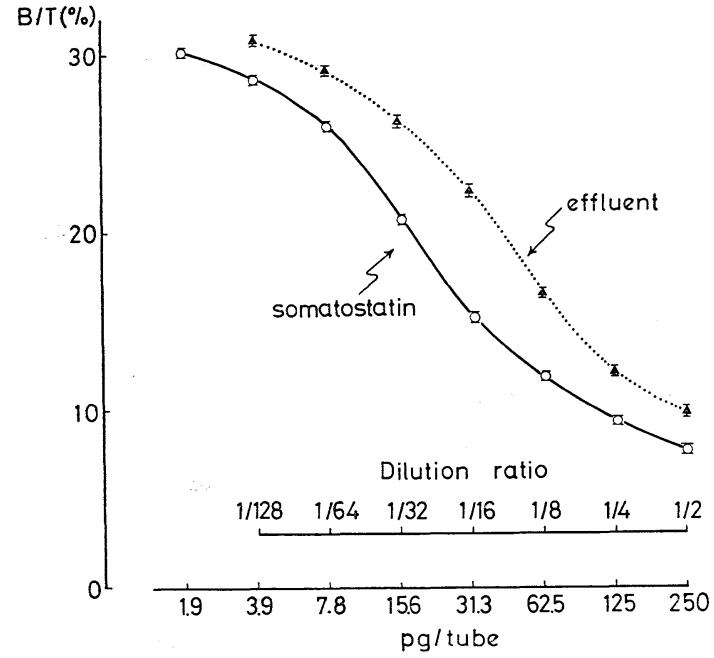

Fig. 2. The dilution curve of effluent in the somatostatin radioimmunoassay.

Fig. 3. The effect of $16.7 \mathrm{~mm}$ glucose on the responses of IRS, IRI and IRG in perifused rat islets in vitro. In one experiment, two chambers, one for normal and the other for diabetic islets, were simultaneously perifused with medium containing $2.8 \mathrm{mM}$ glucose from -20 to $0 \mathrm{~min}$ and from 90 to $120 \mathrm{~min}$. Glucose at the dose of $16.7 \mathrm{~mm}$ was administered from 0 to $90 \mathrm{~min}$. Each point and vertical bar indicates the mean \pm S.E. of four observations. $\mathrm{N}$ represents the response of normal islets and $\mathrm{S}$ represents the response of streptozotocin-induced diabetic islets. Each asterisk indicates the significance of the difference at 5\% level from any of the base line values obtained from -20 to $0 \mathrm{~min}$.
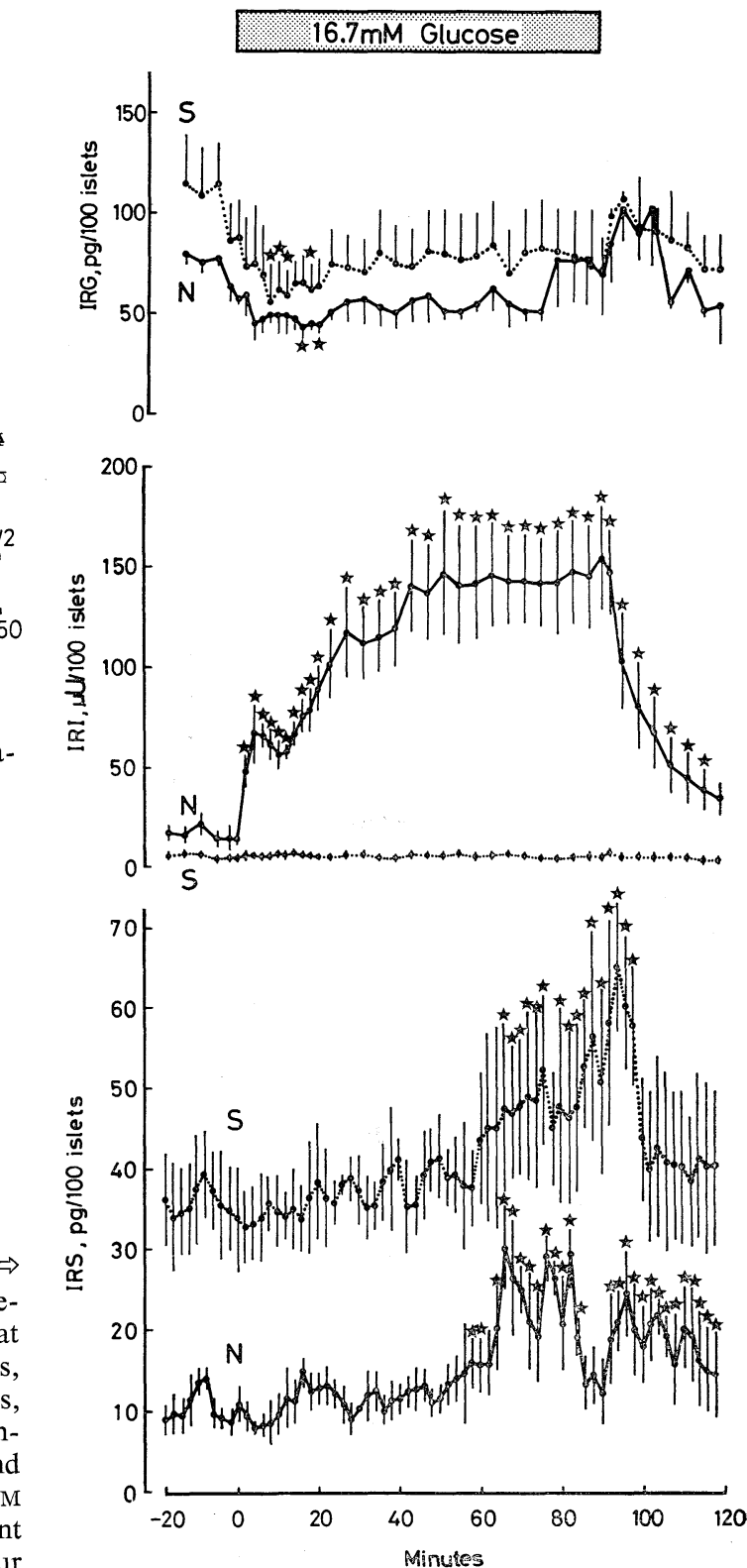


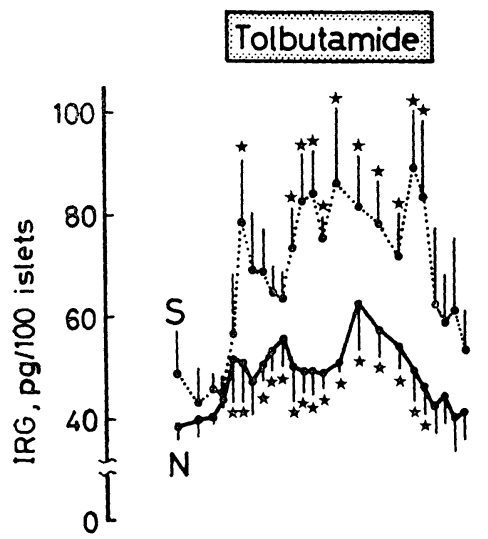

the diabetic group were significantly higher than those of the control group $(p<0.001)$. When the glucose concentration in the medium was decreased to $2.8 \mathrm{~mm}$ IRS levels rose transiently in both groups (Fig 3. lower panel).

The biphasic IRI release was observed with $16.7 \mathrm{~mm}$ glucose in the control group, while the secretion of IRI was negligible in the diabetic group (Fig 3. middle panel). On the other hand, IRG release was suppressed in both groups during the perifusion with $16.7 \mathrm{~mm}$ glucose, and the value returned to each baseline level when the glucose concentration of the medium was decreased form $16.7 \mathrm{~mm}$ to $2.8 \mathrm{~mm}$ (Fig 3 . upper pane1).

IRS, IRI and IRG release by tolbutamide.

As shown in the lower panel of Fig. 4, the perifusion with $400 \mu \mathrm{g} / \mathrm{m} l$ of tolbutamide caused an abrupt IRS release in both groups. The patterns of IRS response to tolbutamide were similar to each other, although the absolute value at each observation period was higher in the diabetic group than in the normal one. The maximal level of

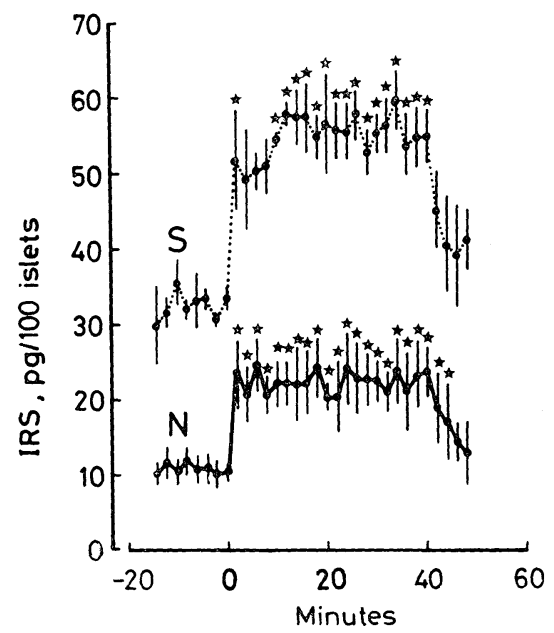

$\hookleftarrow$

Fig. 4. The effect of $400 \mu \mathrm{g} / \mathrm{m} l$ of tolbutamide on the response of IRS, IRI and IRG in perifused rat islets in vitro. In one experiment, two chambers, one for normal islets and the other for diabetic islets, were perifused simultaneously with medium containing $2.8 \mathrm{mM}$ glucose and infused from -20 to $0 \mathrm{~min}$ and from 40 to $50 \mathrm{~min}$. Tolbutamide at a concentration of $400 \mu \mathrm{g} / \mathrm{m} l$ was prepared with the medium containing $2.8 \mathrm{mM}$ glucose and infused from 0 to $40 \mathrm{~min}$. Each point and vertical bar indicates the mean \pm S.E. of four observations. $\mathrm{N}$ represents the response of normal islets and $\mathrm{S}$ represents the response of streptozotocin diabetic islets. Each asterisk indicates the significance of the difference at 5\% level from any of the base line values obtained from -20 to $0 \mathrm{~min}$. 
IRS during the stimulation was $59.8 \pm 3.7$ $\mathrm{pg} / 100$ islets $/ 2 \mathrm{~min}$ in the diabetic group and $24.0 \pm 3.7 \mathrm{pg} / 100$ islets $/ 2 \mathrm{~min}$ in the control group. The former was significantly higher than the latter $(\mathrm{p}<0.001)$.

Tolbutamide stimulated a rapid IRI secretion in the control group but not in the diabetic group. IRG response to tolbutamide was more marked in the diabetic group than in the normal one.

\section{Discussion}

IRG has been located in the D-cells in the pancreas and gastrointestinal tracts (Hökfelt et al., 1975 ; Dubois, 1975). Considering such localization of somatostatin and its pharmacological action in inhibiting pancreatic and gastrointestinal hormones, it is strongly felt that somatostatin regulates the hormone release from the adjacent endocrine cells as a local hormone and plays an important physiological role on the glucose and nutrient homeostasis. In order to prove this theory, many investigations have focused on the relationship among A-, B- and D-cells in the pancreatic islets which is postulated as the "paracrine" hypothesis (Unger, 1977). According to the "paracrine" hypothesis, one of the three secretory products of these three cell types influences the hormonal secretion from its neighboring cells. The abnormal A-, B- and D-cell functions could explain many abnormal pancreatic endocrine states seen in diabetes (Unger and Orci, 1977). However secretory dynamics of somatostatin from $D$-cells of diabetic islets remains obscure.

In the present study, we found out that basal levels of IRS in the effluent of diabetic islets were three times as high as those of normal ones and that IRS responded remarkably to the high concentration of glucose and tolbutamide. These results would reflect the hypertrophy and hyperplasia of D-cells observed in the dia- betic rats (Orci et al., 1976). Such pathological changes in D-cells in the islets might be caused by the prolonged hyperglycemic stimulation secondary to diabetes or by the direct effect of STZ on D-cells.

In our perifusion system IRS was increased $58 \mathrm{~min}$ after exposure to the high concentration of glucose in normal islets. This delayed response was different from the results reported by Ipp et al. (1977) and Schauder et al. (1977), who found an immediate elevation of IRS levels after the high concentration of glucose. On the other hand, Barden et al. (1976) and Weir et al. (1979) did not observe any increase in IRS release following $300 \mathrm{mg} / 100 \mathrm{~m} l$ glucose. The different assay system and the different dose of glucose utilized might account for such discrepancies. The delayed response of IRS to high concentration of glucose was similarly observed in the diabetic group on our study. The significance of such responses to glucose in normal and diabetic islets remains unclear.

It is of interest to note that despite an increase in somatostatin levels in the diabetic islets, glucagon release was twice as high as the normal level. If somatostatin had inhibited glucagon secretion as a local hormone, the glucagon level would be lower in the effluent of the diabetic group than in the control group. Otherwise, D-cells would secrete a large amount of somatostatin in order to restore excessive glucagon secretion in diabetes millitus as described by Buchanan et al. (1973) and Weir et al. (1976).

In the present study, both somatostatin and glucagon were released transiently from islets in respone to an abrupt fall in the glucose concentration from $16.7 \mathrm{~mm}$ to 2.8 mM. A possible role of this somatostatin secretion may be related to the prevention of endogenous insulin overshoot in order to avoid further hypoglycemia. It could be also explained by the fact that increased glucagon release in response to hypogly- 
cemia (Patton et al., 1977; Unger et al., 1962) had a stimulatory effect on D-cells within the islets. This may cause a transient increase in somatostatin secretion, since a high concentration of exogenous and presumably endogenous glucagon (Patton et al., 1976) stimulated the release of somatostatin from rat pancreas.

Also noteworthy is the present finding that the D-cells in STZ diabetic islets which secreted little endogenous insulin responded in a normal fashion to glucose and tolbutamide. In other words, glucose- and tolbutamide-induced endogenous insulin did not exert a stimulatory action on somatostatin release in normal islets through the "paracrine" mechanism. Patton et al. (1977) showed that exogenous insulin did not augment somatostatin release from dog pancreas.

In the present study we showed the secretory patterns of somatostatin, glucagon and insulin responses to glucose and tolbutamide in normal and diabetic islets. However, it was not possible to obtain direct evidence indicating the possible interaction of the secretion of these three hormones. Further investigation will be necessary to elucidate the "paracrine" regulation of islet hormone secretion.

\section{Acknowledgement}

We thank Dr. Shinichi Ohashi, Research Institute for Polymers and Textiles, for the supply of somatostatin and $\left[\mathrm{Tyr}^{8}\right]$-somatostatin used in the present study. We are indebted to Dr. Hiroyuki Sando, the Third Department of Medicine, Tokyo University School of Medicine, for his advice of the preparation of isolated rat islets, to Miss Yoshiko Teraoka for her excellent technical assistance, and to Miss Sumiko Hashimoto and Miss Eiko Yamazaki for the measurement of blood glucose. We also thank Otsuka Assay Laboratory, Tokushima, for help with glucagon measurements, Upjohn company, Kalamazoo, Mich., for the supply of streptozotocin and Hoechst Japan for the supply of tolbutamide.

\section{References}

Alberti, K. G. M. M., N. J. Christensen, S. E. Christensen, Aa. Prange Hansen, J. Iversen, K. Lundbaek, K. Seyer-Hansen and H. Фrskov (1973). Lancet II, 1299.

Arimura, A., H. Sato, A. Dupont, N. Nishi and A. V. Schally (1975). Science 189, 1007.

Barden, N., G. Alvarado-Urbina, J. P. Cote and A. Dupont (1976). Biochem. Biophys. Res. Commun. $71,840$.

Buchanan, K. D. and W. A. A. Mawhinney (1973). Diabetes 22, 793.

Dubois, M. P. (1975). Proc. Natl. Acad. Sci. (U.S.A.) $72,1340$.

Hökfelt, T., S. Efendic, C. Hellerstrom, O. Johansson, R. Luft and A. Arimura (1975). Acta Endocrinol. (Kbh.), Suppl. 200, 5.

Ipp, E., R. E. Dobbs, A. Arimura, W. Vale, V. Harris and R. H. Unger (1977a). J. Clin. Invest. 60,760 .

Ipp, E., R. E. Dobbs, V. Harris, A. Arimura, W. Vale and R. H. Unger (1977b). Ibid. 60, 1216.

Koerker, D, J., W. Ruch, E. Chideckel, J. Palmer, C. J. Goodner, J. Ensinck and C. C. Gale (1974). Science 184, 428.

Kumasaka, T., N. Nishi, Y. Yaoi, Y. Kido, M. Saito, I. Okayasu, K. Shimizu, S. Hatakeyama, S. Sawano and T. Kokubu (1979). Am. J. Obstet. Gynecol. 134, 39.

Lacy P. E. and M. Kostianovsky (1967). Diabetes $16,35$.

Lacy, P. E., M. M. Walker and C. J. Fink (1972). Diabetes 21, 987.

Orci, L., D. Baetens, C. Rufener, M. Amherdt, M. Ravazzola, P. Studer, F. Malaisse-Lagae and R. H. Unger (1976). Proc. Natl. Acad. Sci. (U.S.A.) 73, 1338.

Patel, Y. C. and G. C. Wier (1976). Clin. Endocrinol. 5, 191.

Patton, G. S., E. Ipp, R. E. Dobbs, L. Orci, W. Vale and R. H. Unger (1976). Life Sci. 19, 1957.

Patton, G. S., E. Ipp, R. E. Dobbs, L. Orci, W. Vale and R. H. Unger (1977). Proc. Natl. Acad. Sci (U.S.A.) 74, 2140.

Sawano, S. and T. Kokubu (1977). Proc. Soc. Exp. Biol. Med. 156, 72.

Sawano, S., T. Kokubu and S. Ohashi (1978). Clin. Endocrinol. 26, 127 (Jap.).

Schauder, P., C. McIntosh, J. Arends, R. Arnold, H. Frerichs and S. Creutzfeldt (1976). FEBS Lett. 68, 225.

Schauder, P., C. McIntosh, U. Panten, J. Arends, R. Arnold, H. Frerichs and S. Creutzfeldt (1977). Ibid. $81,355$.

Schusdziarra, V., R. E. Dobbs, V. Harris and R. H. Unger (1977). Ibid. 81, 69. 
Unger, R. H., A. M. Eisentraut, M. S. McCall and L. L. Madison (1962). J. Clin. Invest. 41, 682. Unger, R. H. (1977). N. Engl. J. Med. 296, 998. Unger, R. H. and L. Orci (1977). Diabetes 26, 241.
Weir, G. C., S. D. Knowlton, R. F. Atkins, K. X. McKennan and D. B. Martin (1976). Ibid. 25, 275. Weir, G. C., E. Samols, S. Loo, Y. C. Patel and K. H. Gabby (1979). Ibid. 28, 35. 